\title{
EU's krise er ikke en nord-syd krise
}

Uffe Østergård

\section{EU overlever nok den aktuelle krise, men risikoen ved at trække tiden ud er at befolkningerne tror på alle de gentagelser af gamle stereotype forestil- linger som fylder medierne}

Det ser ikke godt ud for Europa og det europæiske samarbejde. Det har det ikke gjort siden 2008, selv om Lissabon-traktaten slap igennem den irske folkeafstemnings nåleøje og trådte i kraft december 2009. Irerne stemte formentligt kun ja til den beskedne suverænitetsafgivelse, fordi de var i chok over sammenbruddet på det irske boligmarked og den finanskrise der fulgte oven på krakket for Lehman Brothers.

I dag ser landet ud til at være på vej op igen efter hårde besparelser. Men det har blot rettet finansmarkedernes søgelys mod EU's bløde underliv, især Grækenland, Spanien, Portugal og Italien. Dermed ender de franske og tyske banker (og pensionskasser) som har spekuleret i at købe usikre græske statsobligationer, i farezonen. Resultatet er at långivningen mellem de europæiske banker nu er frosset helt til med katastrofale følger for produktion og beskæftigelse.

Spørgsmålet er om det er EU's skyld som folkestemningen og mange journalister synes at mene? Svaret er ja, i den forstand at den fælles valuta har bundet de europæiske økonomier tæt sammen. Selv ikke-eurolande som Danmark er reelt med i euroen i kraft af fastkurspolitikken vi kalder bare vores euro for kroner og udstyrer sedlerne med billeder af eksisterende danske broer i stedet for de abstrakte broer der pryder de 'rigtige' eurosedler. Når krisen har kunnet vokse sig så stor er det bl.a. fordi EU ikke er en føderal stat med deraf følgende magtbeføjelser til at gribe ind i landenes finanspolitik. Derfor har man ikke kunnet bruge de redningsmekanismer som USA med succes anvendte oven på sub- 
prime-krisen. For amerikanerne gav bankredningerne faktisk overskud, fordi staten fik aktier for pengene. De kunne så sælges, da kurserne igen begyndte at stige. Det er ikke bankpakkernes skyld at den amerikanske stat i dag har et kæmpe underskud på sine finanser.

At EU ikke har kunnet gøre den amerikanske stat kunsten efter skyldes, at det er noget nær umuligt at få 27 lande i EU til at enes om hjælp til nødlidende økonomier. Eller 'bare' at få de 17 lande i eurozonen til at enes. Det fremgik tydeligt af situationen i Slovakiet i oktober, hvor eurokrisen bragte en regering til fald. Beslutninger som den amerikanske tager under alle omstændigheder meget længere tid at træffe i EU, og dermed aktualiseres behovet for nye og mere forpligtende samarbejdsformer. Men det indebærer så igen ændringer af traktater - noget både politikere og vælgerne næsten for enhver pris ønsker at undgå.

I stedet ser vi den tyske kansler tage den franske præsident på slæb og agere regering for hele EU. De to står nu i spidsen for den såkaldte Frankfurt-gruppe. Denne gruppe der skal mødes mindst hver måned, består af formanden for euroklubben, Luxembourgs mangeårige premierminister Jean-Claude Juncker, formanden for den Europæiske Centralbank Mario Draghi, formanden for IMF Christina Lagarde, Herman van Rompuy, præsident for det Europæiske Råd, men nu også for eurotopmøderne, formanden for Europa-Kommissionen José Manuel Barroso samt økonomi- og vicekommissær Olli Rehn.

Denne gruppe er ikke helt uden politisk legitimitet, selv om det fremstilles sådan i medierne (bortset fra Politikens skarpsindige Peter Wivel). Den parlamentariske kontrol er ikke sat ud af kraft, men blot overtaget af den tyske Forbundsdag der udfylder rollen som demokratisk kontrollant for hele EU. Angela Merkel har nemlig hele tiden fået godkendt sin politik i Forbundsdagen med stort flertal.

Oppositionen af socialdemokrater og grønne har, i modsætning til oppositionen i Grækenland og Spanien, sat hensynet til Europa over snæver partipolitik og støttet kansleren - der med det yderste af neglene også har fastholdt et flertal af sine egne, den såkaldte 'kanslermajoritet'. Demokratiet i Europa udøves nu af tyskerne, ligesom det er deres økonomi alle håber på skal redde euroen og samarbejdet. Det er ikke et 'tysk Europa' vi her ser udfolde sig, men et 'europæiseret Tyskland'.

\section{De store mod de små}

Diskussionen om hvilke beslutninger der skal til for at redde EU's økonomi har bragt den klassiske strid mellem små og store lande frem i lyset. Dette grundlæggende forhold diskuterer vi ikke meget $\mathrm{i}$ Danmark, hvor man synes at operere ud fra en forestilling om at godt 
nok er vi små, men alligevel store. Danmark kalder sig ikke engang officielt for en småstat. Det holdt Udenrigsministeriet op med i 199091 da de baltiske lande blev frie og Danmark kunne optræde som beskytter af dem. Helt selvovervurderende er den danske holdning ikke. Ser man nøjere efter, er der nemlig i EU efter udvidelsen i 2004 mindst ti lande hvis indbyggertal er mindre end Danmarks. Vi tilhører altså den gruppe af mindre og mellemstore lande der reelt har vundet suverænitet ved at udøve den i fællesskab inden for det regel- og lovbundne samarbejde, som EU - ofte - er.

De lande der har tabt $\mathrm{i}$ indflydelse, er dem der endnu tror, at de er store. Her taler vi primært om Frankrig og Storbritannien. Set i international sammenhæng er disse lande små, trods deres permanente sæde i FN og atombevæbning. Men det erkender de ikke. Som en anonym tidligere formand for Europa-Kommissionen så rammende har udtrykt det: "EU består kun af små lande forskellen er blot at nogle af dem ikke har opdaget det endnu."

De fleste mindre lande i EU har haft en vanskeligere og mere omtumlet historie end Danmark og erkender i modsætning til danskerne at de har vundet $\mathrm{i}$ indflydelse ved samarbejdet. Paradoksalt nok tror mange danskere at vi har tabt lige så meget i selvstændighed og suverænitet som tidligere stormagter som UK og Frankrig.
Et sådant tab led Danmark under Valdemar Sejr der tabte Nordtyskland i 1226, og under Christian 4. og Frederik 3. i midten af 1600-tallet. Siden har Danmark været afhængig af omgivelserne, i eminent grad siden 1864. Men det har den kollektive erindring ikke rigtigt taget konsekvensen af, og derfor har flertallet af danskere ikke villet erkende den reelle indflydelse det regulerede samarbejde i EU giver mindre stater i de fleste situationer. Som tidligere udenrigsminister og mangeårig kommissær Henning Christophersen udtalte i $\mathrm{P} 1 \mathrm{~s}$ program Europa lige nu den 13. november 2011, følger danskerne ikke med i EU-diskussionen i lande der kan sammenlignes med vores eget som Belgien og Nederlandene. I vores orienteringsverden gælder kun 'rigtige' lande som Storbritannien og USA, og efterhånden Tyskland (i form af Berlin) med mindre der er en krise eller en naturkatastrofe.

Man kunne godt ønske sig at politiske iagttagere engang imellem læste bøger om gamle, eller bare anderledes dage. Middelalderhistorikeren Kurt Villads Jensen forsvarede i foråret en spændende disputats om Danmark og Portugal som middelalderlige korstogsriger. (Korstog ved verdens yderste rand. Danmark og Portugal ca. 1000 til ca. 1250, Syddansk Universitetsforlag 2011). Blandt de mange spændende og nybrydende iagttagelser er hans påpegning af, hvor mange ligheder 
der i grunden var mellem disse to lande i denne fjerne fortid. Ligheder der bl.a. forklarer hvorfor en konge som Valdemar Sejr kunne hente en dronning i Portugal. Berengaria har ganske vist fået en hård medfart af 1800-tallets nationalistiske historikere og digtere, men det rokker ikke ved den interessante påpegning af de strukturelle ligheder mellem to for en umiddelbar betragtning så forskellige lande. Måske skulle man lade sig inspirere til at udvide det danske automatperspektiv til i vore dage også at gælde andet end præsidentvalg i USA, der dækkes som om Danmark var en delstat i USA.

Det er de mindre og mellemstore staters indflydelse der er på spil i kampen om hvem der skal bestemme hvad under formuleringen af svaret på gælds- og bankkrisen. Angela Merkel og Nicolas Sarkozy lader som om det er dem - og i mindre grad deres lande - der tager initiativer og kan bestemme udviklingen. Det gør de ikke for godt. Bl.a. fordi deres befolkninger ikke er indforstået, især ikke den tyske, der er ved at blive lige så euroskeptisk som nederlænderne og danskerne længe har været, til trods for at den tyske eksportindustri har tjent mest på det indre marked og euroen.

På den anden side står Kommissionen personificeret ved Manuel Barroso, der kæmper for at beslutninger skal tages i fællesskab efter vedtagne regler, så de små og mellemstore lande sikres indflydelse.
Denne kamp mellem store og små lande om indflydelse er måske det allervigtigste forhold i den aktuelle krise, selv om euroens overlevelse ikke er uden betydning. Men euroens skæbne er så vigtig for Tyskland at det nok lykkes at redde den på den ene eller anden måde, om det så skal koste nogle sydeuropæiske medlemmer som de selv har været letsindige nok til at optage.

\section{Keynes mod Merkel}

En anden vigtig brudflade i kampen om den økonomiske magt i EU er sammenstødet mellem to forskellige nationale traditioner for forholdet mellem regeringer og nationalbanker. På den ene side står den tyske opfattelse, hvor banken kun har til opgave at sikre valutaen mod inflation. På den anden står den mere interventionistiske - eller skulle vi sige keynesianske - franske (og i hvert fald tidligere også danske) tradition for en større politisk indflydelse på pengepolitik og renteniveau. Denne forskel er ikke kun bestemt af nationale traditioner, men afspejler også forskellen mellem en liberalistisk monetær politik og en socialdemokratisk strategi der prioriterer vækst og arbejdspladser højest. Det er derfor vi ser socialdemokrater som tidligere statsminister Poul Nyrup Rasmussen gå ud med en hård kritik af Merkel og Sarkozy og støtte til Barroso (i DR2 Deadline 13. oktober 2011). 
Det er med andre ord både nationale og politiske forskelle der præger diskussionerne i EU.

Det europæiske samarbejde har tidligere været i alvorlig krise. Ja, man kan sige at samarbejdet stort set kun har bevæget sig fremad gennem kriser. Det gjaldt krisen i 1965, hvor Frankrig lod sin stol i Ministerrådet stå tom i et halvt år for at få sin vilje med hensyn til landbrugsordningerne og afvisning af britisk medlemskab. Frankrig vandt og fik indført reglen om at alle lande kan nedlægge veto mod fælles beslutninger.

Krisen blandt de seks i 1960'erne varede reelt helt til topmødet i Haag december 1969, hvor vejen blev banet for optagelsen af Storbritannien (og dermed Danmark og Irland). Samarbejdet gik imidlertid i stå med 1970'ernes økonomiske kriser, der skyldtes meget mere end stigende oliepriser.

Først efter at Frankrig 1981-82 under den nyvalgte socialistiske præsident Mitterrand måtte erkende, at end ikke Frankrig var stort nok til at kickstarte sin økonomi på egen hånd, kom der fart i samarbejdet. Den ansvarlige var Jacques Delors, der havde været ansvarlig for den mislykkede franske økonomiske enegang, men lært at Frankrig nu var blevet så afhængig af det europæiske marked at det ikke kunne føre sin egen økonomiske politik. Som ny formand for Kommissionen relancerede Delors det indre mar- ked i 1985-86 og indførte den Økonomiske og Monetære Union i Maastricht 1991 (med Henning Christophersen som næstformand).

Der var ikke kun økonomiske, men også politiske grunde til ØMU'en, idet den var Frankrigs pris for at acceptere foreningen af Tyskland. Kohl ofrede D-marken af hensyn til det større mål, tysk enhed, men fik aldrig hele sin befolkning med sig. Den uenighed viser sig nu i form af modvilje mod og foragt for de 'slappe og evigt ferierende grækere'. Kritikken af manglende græsk vilje til at betale skat er berettiget. Men det skulle have været tacklet langt tidligere af stærkere europæiske institutioner end dem staterne og borgerne har været villige til at oprette. $\mathrm{Og}$ nu hænger vi på den i fællesskab, også Danmark selv om landet formelt står uden for eurozonen.

\section{Farlige stereotyper}

Skal man dømme ud fra historien overlever EU nok. Ja, unionen kommer muligvis endda styrket ud af krisen. Men først efter at de små store lande som Frankrig og Tyskland har prøvet alle de forkerte løsninger, mens Storbritannien alt for længe har gnedet sig i hænderne i håb om, at City of London igen vil blive finanscentrum på EU's bekostning.

Risikoen ved at trække tiden ud er - ud over de økonomiske omkostninger - at befolkningerne tror på alle de kritikker og gentagelser af 
gamle stereotype forestillinger som fylder medierne. Herunder især genoplivelsen af en forskel mellem nord og syd i Europa. Uden følger er det næppe heller at venstre- og højreorienterede demonstranter i Athens gader spiller nazi-kortet ved at vise tegninger af Merkel i SS-uniform eller gentage gamle britiske påstande fra Margaret Thatchers tid om, at det nu er lykkedes tyskerne at opnå det herredømme over Europa som mislykkedes for Hitler.

Resultatet kan let blive endnu mere modstand mod det samarbejde som nøgternt betragtet er Europas eneste mulighed for at hævde sig i en verden der faktisk er ved at blive global, og hvor vi næppe har råd til at vente på at det skal begynde at gå galt for Kina, Indien, Brasilien og de andre vækstøkonomier. For slet ikke at tale om svækkelsen af EU som eksemplets magt med hensyn til demokrati og menneskerettigheder.

Men alarmklokkerne bør ringe højt og vedvarende, når nogen forsøger at presse eurokrisen ind i en påstået klassisk nord-syd konflikt $\mathrm{i}$ EU. Det er ved at være længe siden at vi har hørt påstanden om 'de ærlige og arbejdsomme protestanter i nord over for de dovne, ferierende katolikker i syd'. Faktisk ikke siden debatten om 'Rom-unionen' som det hed i 1972 under diskussionen om Danmarks tilslutning til Fællesmarkedet. Dengang forestillede mange sig at sydeuropæiske, katol- ske og mafiøse arbejdere ville underbyde det ærlige danske arbejdsmarked og omgøre resultaterne af reformationen og Socialdemokratiets indsats. Italienerne kom bare aldrig, bortset fra et antal restauranter af høj kvalitet.

Den udeblevne sydeuropæiske indvandring og fraværet af katolsk indflydelse i EUropa har mange årsager, men den vigtigste er det drastisk faldende fødselstal i de latinske lande. At kvinderne i Italien og Spanien har indledt en veritabel fødselsstrejke og nu ligger lavest i Europa, hvor Sverige, Danmark og Frankrig ligger højest, skyldes manglende børnepasningsordninger og i det hele taget en børnefjendtlig indretning af velfærdsstaten, der i syd har koncentreret sig om goder til de ældre og etablerede med fast arbejde.

Man kan dårligt sige at den udvikling vidner om, at en særlig katolsk kultur skulle vinde frem på bekostning af 'ærlige' protestantiske dyder, så en tilbagerulning af det sekulariserede Nordeuropa har vi ikke været vidne til, tværtimod

\section{Ansvarsløse sydeuropæere?}

Hvorfor går det så bedre for økonomierne i Nordeuropa, mens Sydeuropa har pådraget sig en statsgæld som resultat af mange års over forbrug? Kan det have noget at gøre med den deling af Europa som skete med reformationerne i 1500-tallet, og at det simpelthen er nærmest 
naturgivent at nordeuropæerne arbejder hårdere, mens sydeuropæerne nyder det gode liv? Det er en udbredt forestilling blandt tyske, finske og nederlandske vælgere - og formentlig også blandt danske hvis vi havde været medlem af eurozonen. Det er vi reelt, men som anført blot uden indflydelse og uden pligt til at bidrage til redningspakkerne.

Derfor fylder den debat mindre i Danmark. Men at der er ikke langt til fordommene om de dovne og ansvarsløse sydeuropæere skal man ikke have deltaget i mange middagskonversationer eller medie-debatter for at opdage.

Man må også indrømme at italienske Berlusconi lever op til enhver kliché om den sorgløse og korrupte sydeuropæiske politiker med sine udtalelser, lumre sange, livsstil og offentlige opførsel over for kvinder. Men græske Giorgos Papandreou virker snarere som en retlinet og stærkt tynget svensk socialdemokrat, når han har været rundt med hatten $i$ hånden for at få hjæelp til at redde sit land. Italiens premierminister Silvio Berlusconi prøvede til det sidste at klare sig over for Merkel og Sarkozy med de dæknings- og indholdsløse forsikringer om alt det han måske kunne tænke sig at gøre, som han har haft held til at besnære et flertal af italienske vælgere med i næsten tyve år.

Det virkede ikke på dem, lige så lidt som det har virket på finansmarkederne, og til sidst måtte han træk- ke sig til fordel for en kedelig og tillidsvækkende økonom med en stor karriere som EU-kommissær, Mario Monti. Om denne vil lykkes med sin politik er dog helt uvist, da han stadig er afhængig af stemmerne fra Berlusconis parti. Men italiensk politik - og vælgerne - har mødt en europæisk og international offentlighed som ikke så let lader sig omdanne til et smagløst italiensk TV-show med små skaldede mænd der siger vittigheder ind i brysterne på storbarmede blondiner med højt opslidsede kjoler. Det er der også mange italienere der er glade for.

\section{'Grüss Gott linjen'}

Hovedproblemet ved at stille Sydeuropa op mod Nordeuropa er at samme retorik genfindes i de enkelte europæiske lande. Tydeligst i Italien med konflikten mellem nord og syd; men også i Spanien, Tyskland, Holland og Belgien taler man om en nord-syd konflikt. Så spørgsmålet er om det er en reel modsætning, eller om det blot er en talefigur som vi bruger til at beskrive de modsætninger med der findes i alle lande.

Mistænksomhedsklokkerne bør ringe, når man konfronteres med en model der passer på for meget. I Tyskland taler man ligefrem om 'Grüss Gott linjen' efter måden man hilser på. Syd for linjen er majoriteten katolikker, mens protestanterne mod nord siger 'Guten Tag'. Problemet er bare at de 'Grüss Gott' hil- 
sende katolikker i det sydlige Tyskland også er de hårdest arbejdende og økonomisk mest succesfulde, mens Bremen og Berlin er de mest forgældede delstater.

Den økonomiske succes i Bayern og Baden-Württemberg der op til Anden Verdenskrig var tilbagestående og domineret af urentable småbrug, har flere årsager. Men skyldes især indvandringen af næsten tre millioner fordrevne tysk talende fra Sudeterne i Tjekkoslovakiet. De repræsenterer stadig et politisk problem, især fordi tjekkerne ikke vil se i øjnene at de begik et overgreb i 1945. Men økonomisk satte den initiativrige og veluddannede indvandring gang i den succesfulde industrialisering, som en gruppe journaliststuderende i en rapport engang gav den træffende overskrift 'HiTech in Lederhosen', hvormed de fremhævede den særegne kombination af avanceret informationsindustri og konservative katolske dyder som længe har præget det dominerende parti, CSU. Og i uddannelsessystemet med bevaring af undervisning i latin og græsk i gymnasiet.

\section{Borger og stat}

Ved nærmere eftersyn findes der utallige skillelinjer i Europa. Østeuropa over for Vesteuropa, lavlande over for bjergområder, orientering mod havet over for orientering mod indlandet for at nævne nogle få.

Vigtigst er forskellene i borgernes syn på staten. Grækenland har aldrig fået opbygget en troværdig stat der fungerer og som borgerne har tillid til. Folk fægter for sig selv, deres familie og venner, og det er nærmest en borgerpligt ikke at betale skat. Det hænger sammen med Grækenlands lange og komplicerede historie, hvor de europæiske stormagter efter den græske selvstændighedskrig mod det osmanniske rige i 1820 'erne indsatte først en bayersk prins, siden en dansk prins som konge. Det var et chok for dem og deres medarbejdere at komme til Athen, der var en lille rodet og snavset landsby uden andet end nogle ruiner som vidnesbyrd om den store fortid over to tusinde år tidligere, som alle europæere havde læst om i gymnasiet. Dette sammenstød mellem idealer og virkelighed er ingen af parterne nogen sinde kommet sig helt over.

Noget tilsvarende gælder for Italien. Selv om dette land blev en større succes som stat end Grækenland, er det aldrig blevet rigtigt samlet. Loyalitet over for staten er så godt som ikke eksisterende, især i Syditalien, hvor staten skal konkurrere med mafiaen om at sikre tryghed og sociale goder. En konkurrence som mafiaen og tilsvarende forbrydersyndikater kun klarer alt for godt. Staten er 'de andre' og derfor noget man snyder.

Borgernes forankring ligger i familien, deraf den socialantropologiske karakteristisk 'amoralsk famili- 
arisme' eller det bedre kendte 'klientelisme' som ikke kun er korruption eller mafiøs adfærd. Udvidede netværk er alternativer til staten, og politiske alliancer bygger først og fremmest på personlige forbindelser, deraf vanskeligheden med at få politiske partier til fungere efter nordeuropæiske begreber.

Trods disse grundliggende fællestræk er det en fejl at slå alle sydeuropæiske lande sammen under samme overnationale katolske hat. Grækerne er nemlig ikke katolikker, men ortodokst kristne i hvert fald siden den kristne kirke splittedes i 1054, reelt sikkert tidligere. Ortodokse er ikke græsk katolske; det er en betegnelse for ortodokse som anerkender Paven som overhoved, men følger ortodoks ritus, ligesom den unierede kirke i Ukraine og enkelte kristne kirker i Mellemøsten.

\section{Arven fra Byzans}

Moderne grækere er arvtagere til den kristne, byzantinske middelaldercivilisation og de næsten fire hundrede års osmannisk-tyrkisk herredømme fra 1453 til 1821, som først sluttede med et stort græsk nederlag i Lilleasien i 1921. Grækenland er et Balkan-land med en politisk kultur der snarest ligner forholdene i Bulgarien, Rumænien, Makedonien, Serbien og Cypern (se Udenrigs 2010:1). I Sydøsteuropa er arven fra den ortodokse kirke og det osmanniske rige vigtigst til forklaring af statens svaghed, kombineret med borgerkrigen efter Anden Verdenskrig 1945-49 og militærdiktaturet 1967-74. Alle disse styrer har brugt staten til at undertrykke deres modstandere, der så har taget revanche når de selv er kommet til magten.

I Frankrig repræsenterer Sarkozy en fransk stat der på overfladen fremtræder som stærk, men som reelt er skrøbelig. Det skyldes franskmændenes tradition for at gå på gaden og protestere i stedet for indgå kompromiser, hvis de da ikke ligefrem laver revolution som det skete i 1958 og 1968 samt selvfølgelig revolutionerne 1789, 1830, 1848 og 1871. Den franske stat kan bedst sammenlignes med støbejern i frostvejr; den kan springe og gør det med jævne mellemrum. Franskmændene er ikke vokset sammen med deres stat som de protestantiske lande Danmark og Sverige.

De homogene skandinaviske samfund har derimod udviklet en stat som borgerne nærmest elsker. Vist betales der høj skat, men de fleste er enige om at man får noget for pengene. Vi forventer det i hvert fald og skuffes, modsat andre europæere, når det ikke sker. Denne forestilling om tryghed og garanti fra staten er sikkert forklaringen på at de nordiske lande altid scorer højt på rundspørger om lykke.

Luther har spillet en rolle for denne situation i Norden og dele af Tyskland og de baltiske lande, på samme måde som Calvin har spillet 
en rolle for de reformerte i Schweiz, Nederlandene og Skotland samt dele af Tyskland, fordi de skilte kirken fra den verdslige magt. Ganske vist på forskellig måde, men resultatet kan sammenlignes.

I Skandinavien blev præsten kongens og senere statens embedsmand, hvilket har givet staten en helt uforholdsmæssig styrke her. Samtidig er præsten ikke et mellemled mellem Gud og mennesker som for katolikker og indtager ikke en privilegeret plads som en hellig mænd. Disse forhold kombineret med den store rolle menigheden spiller for Luther som en 'kirke uden mure' er baggrunden for det stærke lokale selvstyre i kommunerne, der tidligere har præget den offentlige forvaltning, altså staten.

Lidt tilspidset kan man sige at lutherdommen via en lang række mellemregninger har ført til socialt demokrati og dermed velfærdsstaten. Og den tror nordeuropæerne på, indtil det modsatte er bevist, hvorimod det i mange andre dele af Europa, og ikke kun i syd, er omvendt.

Skal man forstå mistænksomheden over for statsmagten i Syd- og $\varnothing$ østeuropa spiller de lange linjer og forskellene i politisk kultur en rolle. Men det er især erfaringerne fra det blodige og totalitære 20 . århundrede der forklarer forskellene. De fleste sydeuropæiske lande var diktaturer indtil for nylig, som de kommunistiske lande i Øst- og Centraleuropa var det. Det har efterladt en kon- frontatorisk politisk kultur hvor vinderen tager det hele, hvis det er muligt. Der er ingen større forskel på situationen i Ungarn og i Grækenland i den henseende. Polen kom heldigt ud af sit valg tidligere i år og blev heller ikke ramt så hårdt af finanskrisen som resten af Europa. For første gang genvandt en siddende regering magten med mandat til at føre en forsonlig politik over for naboerne. Men man skal ikke følge debatten i Polen særligt nøje for at blive bekymret over den retoriske uforsonlighed.

Uforsonligheden er næsten lige så hård i Italien, hvor Berlusconi har udnævnt sine modstandere i centrum-venstre til 'kommunister', på samme måde som han gør det med de undersøgelsesdommere der har ført de mange sager mod ham for bestikkelse og forbindelser til mafiaen. Det har han haft held til, fordi Italien pga. den kolde krig aldrig fik afsluttet opgøret i borgerkrigen 1943-45. I mange år talte politiske iagttagere som Girogio Galli om 'bipartismo imperfetto' (et uperfekt topartisystem), fordi venstrefløjen ikke måtte komme til magten, uanset hvor mange stemmer de fik. Da det så lykkedes et par gange efter 1992, ødelagde den det for sig selv pga. intern splittelse.

Om det vil ske igen er umuligt at forudse. Men den hårde stil der umuliggør kompromiser, også de mest nødvendige, dominerer stadig Italien som så mange andre lande $\mathrm{i}$ 
EU. Deraf behovet for eksterne indgriben i form af trojkaer, Frankfurtgrupper og lignende. Det er ikke nødvendigvis lig med suspension af demokratiet, men snarere beskyttelse af demokratiet mod inkompetente politikere og en hadefuld politisk kultur der kun kender til at rage så meget som muligt til sig selv og sin egen gruppe. En sådan politisk kultur behøver man ikke at være sydeuropæer eller katolik for at have.

\section{EU's fremtid}

Grunden til Europas aktuelle krise blev lagt i årene før og efter Murens fald i 1989, da den økonomisk-monetære union blev konstrueret. Frankrig fik europæiseret D-marken i 1990 som den politiske pris for genforeningen af Tyskland. Det grundlæggende strukturelle problem ved ØMU'en er at den ikke har nogen politisk overbygning.

Løsningen bliver næppe en traktatændring, dertil skræmmer sporene fra de seneste traktater for meget. Snarere en mere beskeden fremgangsmåde hvor kravene til finanspolitikken skrives ind i forfatningerne, kombineret med mindre tekniske justeringer af Lissabon-traktaten. Det er muligvis også en bedre metode, for det kan medføre at EU bliver nærværende i nationalstaterne. Grundlæggende er EU stadig et samarbejde mellem nationalstater. Det er dér magten ligger, som man tydeligt kan se, når krisen rigtigt kradser som den gør i øjeblikket.

Reformationen fandt sted i 1500tallet, EF blev grundlagt i 1957, Danmark blev medlem i 1973 og euroen først indført i 2002. På den baggrund kan det overraske at nogen undres over, at forholdet mellem borger og stat er forskelligt i de forskellige lande. EU's historie handler i høj grad om en stadig snævrere union mellem folkene, som der stod i traktaterne indtil formuleringen gled ud med præamblen til Lissabon-traktaten. Da daværende kommissionsformand Jacques Delors i slutningen af 1980'erne bestilte en fælles europæisk lærebog i historie, ønskede han en fremstilling af kontinentet som en organisk helhed, ikke en mosaik af kulturer.

Delors selv mente at historikernes opgave var at sætte integrationsprocessen i perspektiv. Har denne EUhistorieskrivning ignoreret forskellighederne i Europa til fordel for den politiske forening? Den officielle Bruxelles-mytologi bygger på et helgen-galleri med Konrad Adenauer, Paul-Henri Spaak, Robert Schumann, Alcide De Gasperi og Jean Monnet i spidsen, men i virkeligheden hører også 'anti-europæere' som Charles de Gaulle og Winston Churchill med. Man fortæller ikke hele sandheden, kun en redigeret udgave.

En langt bedre og mere realistisk fremstilling af problemer og modsætninger - men også løsninger findes i Jean Monnets erindringer 
fra 1976. De er bl.a. oversat til dansk (Mit Liv, Forum 1981), men synes ikke at have efterladt påviselige spor i den danske offentlighed. Her fremgår det ellers klart at det er konflikterne, som i en tøjlet udgave udgør Europa. Men også hvad der kan gøres for at samle de modstridende interesser i fælles handling. Europas historie er stort set at kæmpe med naboerne og at alliere sig med naboens fjende, der af den grund bliver ens egen ven.

Det er historien om dette splittede kontinent i det 20. århundrede som en moderne historiker med speciale i Balkan, Mark Mazower, i 1998 sammenfattede i bogen Dark Continent. Den handler om totalitarisme fra højre såvel som venstre, om folkemord og ekstrem nationalisme. Kort sagt alt det som ikke nævnes i skåltalerne om menneskerettigheder, demokrati og afvisning af dødsstraf, men som udgør en mindst lige så sand fortælling.

Det er derfor nok så meget modsætninger der binder europæerne sammen, som fælles idealer. Den udskældte EU-elite ved til gengæld at alternativet til ikke at hænge sammen er meget værre. Især for de små og mellemstore lande. Dertil kommer presset udefra. Selv om europæerne ikke er meget for at indrømme det, var det reelt USA der tog initiativet til det europæiske samarbejde, ligesom det i dag er Kina der presser på for at få euroen til at overleve. Tysklands tidligere udenrigsminister, den grønne Joschka Fischer, har udtalt at selv om europæerne indbyrdes oplever hinanden som meget forskellige, så er Europa set udefra en enhed.

Den aktuelle udvikling tyder dog ikke på at flertallet af borgerne er enige i den betragtning. Anti-EU partier vinder frem ved at kritisere samarbejdet. I Danmark er Dansk Folkeparti mod EU, i eurolande som Finland og Nederlandene vinder de EU-skeptiske Sande Finner og Frihedspartiet frem. Hvorfor?

Fra et finansielt perspektiv er kritikerne naive og uden anelse om, hvor farligt det er at sejle rundt som en papirbåd på et oprørt hav, omgivet af finansielle spekulanter. Enten kæntrer man, eller også ender man i lommen på andre.

Direktøren for Nationalbanken, Niels Bernstein, beretter at han næsten ikke sov i en hel uge i oktober 2008, da valutaen strømmede ud af banken. Her ville det have været rart at være med i euroen, alle dens aktuelle kvaler til trods. Men den bekymring har ikke bredt sig i befolkningen, der lever i tryg forvisning om at tyskerne eller nogle andre nok skal hjælpe os. Det gør de måske. På en god dag, hvor de mener at have råd og i øvrigt er i godt humør.

Uffe Østergård er professor i europaisk historie ved CBS. 